\title{
PENGEMBANGAN PRODUK RAGA DAYANG MENJADI TAS ROTAN KONTEMPORER
}

\author{
Arthur A. Sembiring ${ }^{1 *}$, Andar Bagus Sriwarno ${ }^{2 *}$, Dian Widiawati ${ }^{*}$ \\ Magister Desain Fakultas Seni Rupa dan Desain \\ Institut Teknologi Bandung \\ Jl. Ganesha, No. 10, Kel. Lb Siliwangi, Kec, Coblong, Kota. Bandung, Kode Pos 40132 \\ Jawa Barat, Indonesia \\ Email: arthursm@students.itb.ac.id
}

\begin{abstract}
Abstrak
Raga dayang adalah salah satu dari sekian banyak produk kerajinan tradisional Karo. Raga dayang merupakan produk kerajinan anyaman rotan. Desa Kuta Male adalah salah satu desa perajin raga dayang. Produk ini merupakan produk pelengkap dalam pernikahan adat Suku Karo. Dahulu, merupakan sarana bawa bagi perempuan Karo bila bepergian maupun berbelanja. Sekarang ini, masyarakat Karo pada umumnya sudah tidak lagi memiliki produk tradisional ini. Jumlah perajinnya semakin berkurang. Hal ini dapat berdampak pada tradisi menganyam rotan di Kabupaten Karo lambat laun menuju kepunahan. Tidak adanya inovasi desain yang sesuai dengan perkembangan zaman merupakan faktor penyebab kepunahan tersebut. Pengembangan produk raga dayang menjadi tas rotan kontemporer bertujuan untuk mengangkat kembali keterampilan perajin raga dayang dan salah satu budaya lokal masyarakat Karo dalam gaya desain kontemporer. Metode penelitian yang dipakai dalam penelitian ini adalah kualitatif deskriptif melalui pendekatan eksperimental dan ATUMICS. Metode kualitatif deskriptif digunakan untuk mengolah data awal hingga peneliti menemukan teknik/cara menganyam, corak anyaman, ornamen, bentuk dasar, dan cara pembuatan raga dayang, setelah itu peneliti menggunakan metode ATUMICS dalam melakukan pengembangan desain. Selanjutnya desain-desain tersebut diujicoba (eksperimental) sehingga menghasilkan purwarupa (prototype). Hasil penelitian menunjukkan raga dayang dapat dikembangkan menjadi produk rotan alternatif dengan ciri khas ornamen Karo.
\end{abstract}

Kata Kunci: pengembangan, raga dayang, anyaman, rotan.

\begin{abstract}
Raga Dayang is one of the many traditional Karo craft products. Raga Dayang is a rattan wicker craft product. Kuta Male Village is one of the village craftsmen Raga Dayang. This product is a complementary product in the traditional wedding of Karo people. Previously, it was a means of carrying for Karo women when traveling or shopping. Nowadays, Karo people in general are no longer having this traditional product. The number of craftsmen is decreasing. It has an impact on the tradition of weaving rattan in Karo district gradually towards extinction. The absence of design innovations that are in accordance with the times is a factor in the extinction. The development of Raga Dayang products into contemporary rattan bags aims to revive the skills of the Raga Dayang craftsmen and one of the local cultures of the Karo people in a contemporary design style. The research method used in this research is descriptive qualitative through an experimental approach and ATUMICS. Descriptive qualitative method is used to process preliminary data until the researcher finds the weaving techniques, patterns of weaving, ornaments, basic shapes, and how to manufacture the Raga Dayang, after that researchers use the ATUMICS method in conducting design development. Furthermore, the designs were tested (experimental), resulting in prototypes. The results showed Raga Dayang can be developed into an alternative rattan product with the characteristic of Karo ornaments.
\end{abstract}

Keywords: development, raga dayang, woven, rattan..

\section{PENDAHULUAN}

Suku Karo di Sumatera Utara memiliki beragam seni kerajinan tradisional. Seni kerajinan tradisional disini identik dengan peralatan/produk yang biasa digunakan masyarakat Karo dalam kehidupan sehari-hari. Peralatan yang biasa digunakan dibagi atas beberapa bagian, alat-alat yang digunakan untuk makan sirih, alat-alat untuk keperluan upacara adat dan rumah 


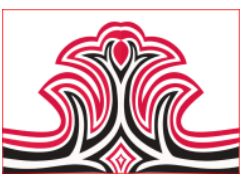

tangga, alat musik, perhiasan, kain tenun dan lain sebagainya. A.G. Sitepu, dalam bukunya Mengenal Seni Kerajinan Tradisional Karo, membagi produk kerajinan tradisional tersebut menjadi 16 jenis, yang tiap jenisnya terdiri dari berbagai macam produk. Dari beragam seni kerajinan tradisonal tersebut kini banyak hanya bisa dilihat di museum, beberapa masih bisa ditemukan dalam keseharian masyarakat Karo, salah satunya adalah Raga Dayang. Raga dayang, dahulu digunakan untuk tempat kain dan kebutuhan lain oleh perempuan Karo bila bepergian maupun berbelanja (berfungsi sebagai tas), tetapi sesuai dengan perkembangan zaman, hal tersebut sudah tidak banyak dilakukan lagi. Raga dayang kini lebih banyak digunakan dalam acara pesta pernikahan adat Karo. Masyarakat Karo kebanyakan sudah tidak lagi memiliki produk tradisional ini. Hanya dimiliki oleh pihak-pihak tertentu baik sebagai koleksi pribadi atau untuk disewakan dan dipinjamkan dalam acara adat. Raga dayang memang lebih banyak digunakan sebagai produk pelengkap dalam acara pernikahan adat Karo.

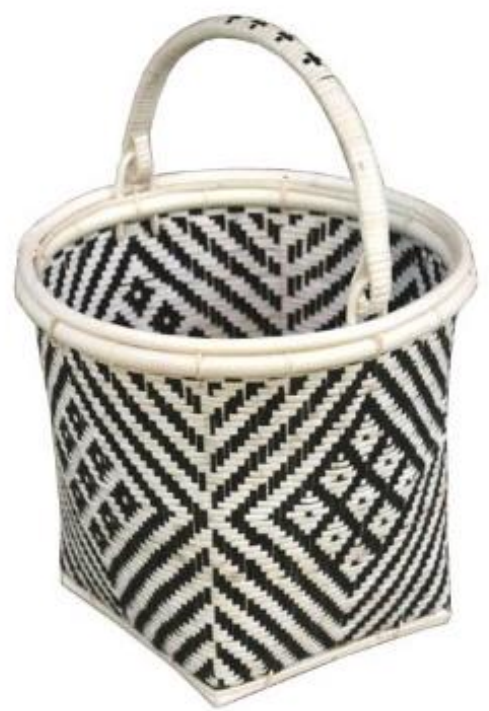

Gambar 1. Produk Kerajinan Tradisional Raga Dayang (Sumber: Arthur A. Sembiring., 2019).

Salah satu desa di Kabupaten Karo yang menekuni kerajinan raga dayang tersebut adalah Desa Kuta Male, Kabupaten Karo, Sumatera Utara. Desa Kuta Male berada di kecamatan Kuta Buluh, Kabupaten Karo, provinsi Sumatera Utara. Terletak $42 \mathrm{~km}$ ke arah barat dari ibukota kabupaten, Kabanjahe. Jarak dari Medan, ibukota provinsi Sumatera utara menuju Desa Kuta Male sekitar 118,3 km. Membutuhkan waktu sekitar 4-5 jam perjalanan darat. Desa ini tanahnya subur, masyarakatnya hampir $90 \%$ petani. Hanya $10 \%$ dari masyarakatnya yang menggeluti
Gorga : Jurnal Seni Rupa

Volume 09 Nomor 01 Januari-Juni 2020

p-ISSN: 2301-5942 | e-ISSN: 2580-2380

profesi sebagai perajin raga dayang. Di desa ini perajinnya sudah tergabung dalam satu komunitas (sanggar), Sanggar Raga Dayang Desa Kuta Male. Sanggar ini dipimpin oleh seorang ketua, ketua sanggar saat ini adalah bapak Erwin Surbakti. Dalam sanggar bergabung sekitar 30 orang perajin. Sanggar ini merupakan aset pemerintah desa Kuta Male. Kepala Desa Kuta Male, John Wilkanris Sembiring, langsung memantau sanggar kerajinan tradisional ini. Sayangnya, infrastruktur jalan menuju desa Kuta Male masih buruk, kondisi jalannya berbatu-batu dan sebagian masih tanah liat, sehingga cukup melelahkan jika hendak berkunjung ke sentra kerajinan raga dayang Kuta Male.

Penggunaan produk tradisional tersebut lebih banyak dalam upacara adat dan seremonial mengakibatkan tidak banyak orang yang menekuni kerajinan raga dayang sebagai mata pencaharian utama, pada umumnya orang-orang menjadikannya sebagai mata pencaharian sampingan. Jumlah perajinnyapun tidak banyak lagi. Hal itu mengakibatkan raga dayang tidak mengalami pengembangan yang berarti, pemasarannya pun terbatas. Pada umumnya produkproduk tradisional Karo di pasar-pasar tradisional kabupaten dan kecamatan, contohnya pasar tradisional Kabanjahe. Tidak banyak masyarakat Sumatera Utara yang mengenal Desa Kuta Male sebagai desa penghasil kerajinan raga dayang, bahkan masyarakat Karo pun tidak banyak yang mengetahuinya.

Sebenarnya raga dayang bersama dengan uis Karo (kain tenun Karo) sudah menjadi ikon kerajinan tradisional Karo. Dalam setiap pameran/event baik itu skala daerah maupun nasional raga dayang diikutsertakan. Hanya saja raga dayang belum bisa menyamai uis. Uis sudah memiliki diversifikasi produk yang beragam dengan harga jual yang beragam pula, mulai dari harga jual rendah sampai tinggi. Sedangkan raga dayang belum memiliki pengembangan produk yang berarti, hanya sebatas pada pengembangan ukuran dan ornamen saja.

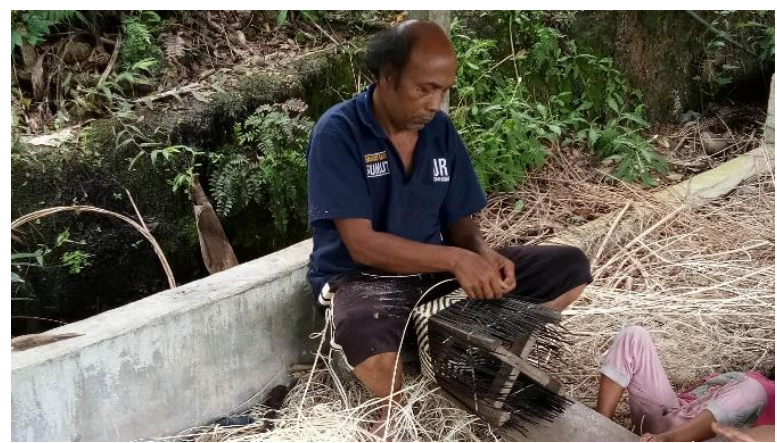


Gambar 2. Perajin Raga Dayang di Desa Kuta Male (Sumber: Arthur A. Sembiring., 2019).

Pengembangan desain dengan berbagai teknik, bahan, bentuk motif telah banyak kita jumpai di masyarakat. Pengembangan tersebut di satu sisi menunjukkan adanya upaya untuk pelestarian budaya bangsa, sedangkan di sisi lain untuk pengembangan kreativitas masyarakat pendukungnya, kebutuhan ekonomi, sosial, menambah devisa, dan sebagainya. Kriya modern ataupun kontemporer merupakan pengembangan dari kriya tradisional ataupun kreasi baru sebagai bentuk inovasi dan kreasi desainer untuk memenuhi tuntutan kebutuhan dan perkembangan jaman. Dalam konteks tersebut terjadi pergeseran nilai-nilai yang bersifat spiritual menjadi nilai material yang sifatnya praktis (Martono, 2010).

Arah pengembangan desain kerajinan tradisional raga dayang dalam penelitian ini adalah tas rotan kontemporer. Produk tas rotan kontemporer yang dimaksudkan disini adalah tas rotan untuk perempuan berbentuk tote bag. Sedangkan penerapan gaya desain kontemporer pada tas rotan tersebut bertujuan untuk mengangkat kembali kerajinan raga dayang dalam tampilan desain masa kini. Melalui hasil observasi awal menunjukkan masyarakat Karo tradisional sudah menggunakan raga dayang ini sebagai wadah ataupun sarana bawa.

\section{KAJIAN TEORI}

\section{Tradisi, Modernitas, dan Keberlanjutan}

Istilah 'tradisi' dalam konteks ini merujuk kepada apa yang dianggap sebagai 'tradisi lama'. Ini adalah kondisi dimana sebagian besar terkait dengan istilah seperti tua, masa lalu, ketinggalan jaman, pra-industri, sederhana, buatan tangan, asli, bahasa daerah, dan ekonomi yang kurang terintegrasi. Ini merupakan kebalikan dari istilah 'modern' yang mengekspresikan kekinian, perkembangan pesat, dinamis, baru, hi-tech, industri, buatan mesin, teknologi baru, inovatif, dan progresif. Kondisi yang ideal untuk tradisi adalah, kondisi dimana tradisi itu bisa terus berkembang sesuai dengan kondisi kontemporer (kondisi masa kini). Kondisi yang acapkali terjadi justru sebaliknya, dimana tradisi (masa lalu) cenderung gagal terhubung dengan masa kini. Upaya dan solusi kreativitas dibutuhkan dalam kondisi ini. Diskontinuitas dan ketidakmampuan untuk terhubung dengan modernitas ini kemudian menghasilkan ide kesinambungan, antara tradisi lama dan modernitas. Keberlanjutan telah menjadi konsep utama dalam membentuk kembali dan mempertahankan dunia kita ini untuk memastikan keberlanjutan kehidupan saat ini dan masa yang akan datang. Pada umumnya, orang-orang
Gorga : Jurnal Seni Rupa

Volume 09 Nomor 01 Januari-Juni 2020

p-ISSN: 2301-5942 | e-ISSN: 2580-2380

seringkali melihat keberlanjutan dengan mengacu hanya pada aspek ekologi dan lingkungan, akan tetapi keberlanjutan membutuhkan juga aspek ekonomi, sosial, dan kultural (McCoubrey dikutip dalam Nugraha, Adhi, 2012). Hal tersebut seringkali membutuhkan kompromi-kompromi, dan tantangannya adalah mencari kemungkinan yang dapat diwujudkan secara optimal.

\section{Pengembangan Kerajinan Tradisional}

Keahlian dan keunikan kerajinan tradisional harus dikembangkan untuk menarik pasar yang lebih besar. Kompetisi ini tidak mudah bagi perajin, baik secara finansial maupun budaya. Harus dilakukan beberapa strategi inovasi untuk memfasilitasi pengrajin dalam menghasilkan ide-ide berdasarkan nilai tradisional mereka, sekaligus untuk memastikan keberlanjutan mereka dalam konteks global. Sebagian besar industri kerajinan Indonesia yang terletak di daerah pedesaan bersifat tradisional dan berakar pada masa lalu (Matsumoto, T. \& Roy, T. dikutip dalam Zulaikha, E., Brereton, M., 2011). Perajin mewarisi pekerjaan dari para pendahulu mereka, yang adalah orang tua mereka, kakek-nenek, kakek-nenek buyut dan sebagainya. Industri kerajinan tradisional ini mungkin telah ada selama beberapa dekade, bahkan ratusan tahun.

Skala industri tradisional biasanya merupakan industri skala kecil yang dioperasikan oleh sejumlah kecil karyawan (Matsumoto dikutip dalam Zulaikha, E., Brereton, M., 2011) berdasarkan hubungan keluarga atau lingkungan. Industri tradisional menggunakan organisasi non-perusahaan, tidak didasarkan pada manajemen profesional. Peralatan yang digunakan dalam industri tradisional umumnya merupakan peralatan yang biasa dimiliki perajin dan tidak menggunakan teknologi canggih (Roy, T. dikutip dalam Zulaikha, E., Brereton, M., 2011). Mereka hanya menggunakan tenaga manusia atau konsumsi minimum bahan bakar atau listrik.

Menurut Cappetta, Cillo dan Ponti (dikutip dalam Zulaikha, E., Brereton, M., 2011) terdapat dua jenis strategi inovasi yang dapat diterapkan dalam pengembangan kerajinan tradisional : 1) Inovasi yang digerakkan oleh pasar. Strategi dalam inovasi ini bergantung pada permintaan pasar yang berfluktuasi. Pelanggan pun sadar harga dan kurang loyal terhadap merek (Tran dikutip dalam Zulaikha, E., Brereton, M., 2011). 2) Inovasi yang digerakkan oleh identitas. Strategi dalam inovasi ini didorong oleh identitas tergantung terutama pada desainer yang berbakat dan identitas gaya dari sebuah merek (brand). Faktor 
kunci keberhasilan untuk strategi ini adalah identitas gaya dan produk terbatas (limited product) yang sangat berkualitas, yang dapat memberikan manfaat margin tinggi bagi produsen (Tran dikutip dalam Zulaikha, E., Brereton, M., 2011).

Industri kerajinan dapat menerapkan strategi yang didorong oleh identitas dengan membuat produk terbatas yang berfokus pada pengungkapan keaslian lokal. Apalagi itu harus dibuat sebagai karya seni dengan pengerjaan yang berkualitas tinggi. Namun demikian, strategi ini juga mengandung risiko yang tinggi mengingat situasi pasar yang tidak menentu.

Sebagian besar industri kerajinan di Indonesia, bahkan industri tradisional, menggunakan strategi yang digerakkan oleh pasar. Hal ini dapat dimengerti mengingat tidak banyak industri kerajinan yang secara konsisten mengembangkan produk baru dengan identitas lokal yang kuat. Sebagian besar industri kerajinan mengalami stagnasi pengembangan produk dan mereka menghasilkan produk serupa selama bertahun-tahun, sehingga produk yang ada mudah direproduksi oleh produsen.

\section{Metode ATUMICS}

Prinsip utama dari metode ATUMICS (Artefact Technique Utility Material Icon Concept Shape) adalah tentang pengaturan, kombinasi, integrasi, atau campuran antara unsur-unsur dasar tradisi dengan unsur-unsur modernitas. Pada tingkat praktis, metode ATUMICS adalah alat untuk mencari kemungkinan membuat objek baru yang terinspirasi dari tradisi, dengan menata ulang dan mengintegrasikan keenam unsur tradisi dan modernitas. Ide dari metode ATUMICS adalah menggabungkan beberapa elemen tradisi dengan beberapa elemen modernitas. Sebuah artefak, objek, produk, dilihat dari dua tingkat keberadaan utama: level mikro dan level makro. Level mikro sebagian besar berurusan dengan sifat teknis dan kinerja suatu objek. Ini adalah tentang bagaimana mencari pengaturan ideal dari enam elemen mendasar dari suatu objek: tecnique, utility, material, icon, concept, dan shape. Level makro sebagian besar berurusan dengan aspek yang lebih luas; semangat dan aspek motivasi (cultural, social, ecological, econimic, survival, dan self-expression) yang dengannya objek diproduksi. Ini adalah bagaimana menemukan keseimbangan yang tepat antara berbagai aspek: kultural, sosial, ekologi, ekonomi, kelangsungan hidup, atau ekspresi diri dalam penciptaan objek baru. Dalam konsepsi metode ATUMICS, penciptaan objek harus mengintegrasikan kedua level ini, level mikro dan level makro.

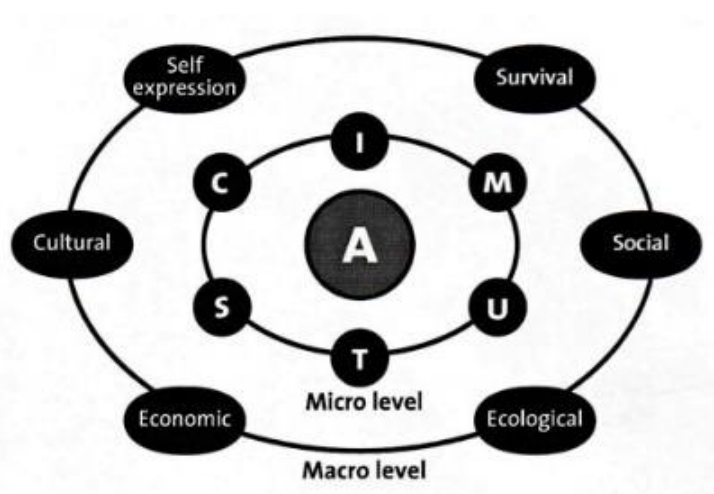

Gambar 3. Elemen-elemen Mikro dan Makro yang Terdapat dalam Metode ATUMICS

(Sumber : Nugraha, Adhi. 2012).

\section{METODE PENELITIAN}

Penelitian dan pengembangan desain produk tas rotan kontemporer ini menggunakan metode kualitatif deskriptif melalui pendekatan eksperimental dan ATUMICS. Metode kualitatif deskriptif digunakan untuk mengolah data awal dan menganalisis keadaan Desa Kuta Male, berikut perajin dan produk raga dayang, dengan tujuan mengetahui kemampuan perajin, teknik/cara anyam yang digunakan, bahan baku, bentuk dan fungsi produk, serta proses pembuatan produk. Metode ATUMICS digunakan dalam proses pengembangan desain, melalui eksperimen perubahan bentuk, ukuran, motif anyaman, dan penggunaan material tambahan.

\section{HASIL DAN PEMBAHASAN}

\section{Hasil}

Karena keberadaan raga dayang yang semakin tersisihkan maka dilakukan pengembangan yang bertujuan untuk meningkatkan nilai produk dengan cara menghasilkan produk baru. Peningkatan nilai produk tersebut dilakukan dengan cara memadukan nilai fungsi (functional), simbolik (symbolic), dan pengalaman perajin (experience). Raga dayang yang pada awalnya merupakan produk yang penggunaannya lebih banyak dalam acara ritual adat dikembangkan menjadi produk sarana bawa (tas rotan) kontemporer. Perancangan dilakukan dengan menggunakan metode ATUMICS, yang menghasilkan produk baru, dengan fungsi yang lebih maksimal, melalui eksperimen perubahan bentuk, ukuran, dan motif anyaman.

Tas rotan yang dihasilkan terdiri dari 2 jenis, tas rotan jenis tas selempang (Gambar 4) dan jenis tas sandang (Gambar 5). 

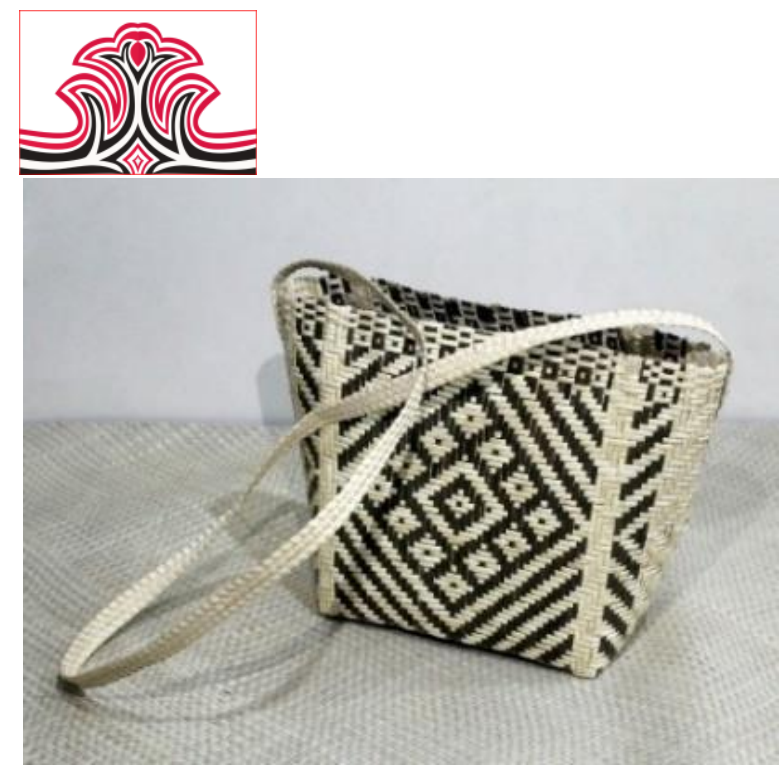

Gambar 4. Tas Rotan Jenis Tas Selempang (Sumber: Arthur A. Sembiring., 2019).

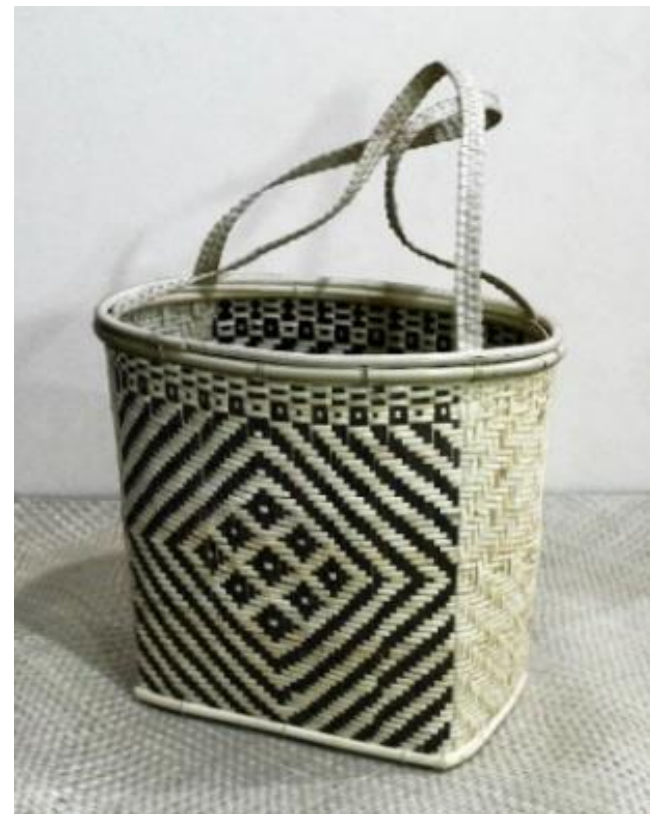

Gambar 5. Tas Rotan Jenis Tas Sandang

(Sumber: Arthur A. Sembiring., 2019).

\section{Pembahasan}

Pengembangan produk dilakukan dalam 3 tahapan: 1) Tahap pemetaan produk lama dan pengembangan produk baru dengan mengolah 6 unsur: technique, utility, material, icon, concept, dan shape, yang merupakan unsur-unsur dalam metode ATUMICS. 2) Tahap perancangan produk (sketsa). 3) Tahap pembuatan purwarupa (prototype).

\section{1).Tahap Pemetaan Produk Lama dan Pengembangan Produk Baru}

Tabel 1. Tahap Pemetaan dan Pengembangan Produk

\begin{tabular}{|c|l|c|}
\hline ATUMICS & \multicolumn{1}{|c|}{$\begin{array}{c}\text { Produk } \\
\text { Lama }\end{array}$} & $\begin{array}{c}\text { Pengembang } \\
\text { an Produk }\end{array}$ \\
\hline $\begin{array}{c}\text { Teknik } \\
\text { (Technique) }\end{array}$ & $\begin{array}{l}\text { Dianyam manual } \\
\text { dengan teknik anyam } \\
\text { lingkar. }\end{array}$ & $\begin{array}{c}\text { Teknik anyam } \\
\text { dipertahankan. }\end{array}$ \\
\hline
\end{tabular}

Gorga : Jurnal Seni Rupa

Volume 09 Nomor 01 Januari-Juni 2020 p-ISSN: 2301-5942 | e-ISSN: 2580-2380

\begin{tabular}{|c|c|c|}
\hline & $\begin{array}{l}\text { Cara anyam ini sudah } \\
\text { dilakukan turun- } \\
\text { temurun. }\end{array}$ & \\
\hline $\begin{array}{l}\text { Fungsi } \\
\text { (Utility) }\end{array}$ & $\begin{array}{l}\text { Fungsi utama dalam } \\
\text { acara adat adalah } \\
\text { sebagai wadah untuk } \\
\text { sumbangan pengantin } \\
\text { dalam pesta adat } \\
\text { pernikahan Karo (acara } \\
\text { cokong-cokong). } \\
\text { Digunakan juga } \\
\text { sebagai sarana bawa } \\
\text { alat-alat memakan sirih } \\
\text { dan pakaian oleh } \\
\text { sebagian perempuan } \\
\text { Karo bila bepergian } \\
\text { atau menghadiri pesta } \\
\text { adat. }\end{array}$ & $\begin{array}{l}\text { Tas rotan } \\
\text { kontemporer }\end{array}$ \\
\hline Material & $\begin{array}{l}\text { Rotan yang terdapat di } \\
\text { Kabupaten Karo. } \\
\text { Rotan sega (Calamus } \\
\text { caesius), yang dalam } \\
\text { Bahasa Karo disebut } \\
\text { dengan ketang rontih. } \\
\text { Sebagian material } \\
\text { diberi warna hitam } \\
\text { dengan pewarna alami } \\
\text { daun cinah (dalam } \\
\text { Bahasa daerah Karo) }\end{array}$ & $\begin{array}{l}\text { Material dan } \\
\text { pewarnaan } \\
\text { dipertahankan. }\end{array}$ \\
\hline Icon & $\begin{array}{l}\text { Menggunakan motif } \\
\text { anyam tepas. } \\
\text { Setiap produk } \\
\text { memiliki ornamen } \\
\text { yang berbeda-beda. } \\
\text { Ornamen yang } \\
\text { umumnya terdapat } \\
\text { pada produk raga } \\
\text { dayang: bunga gundur, } \\
\text { mata-mata lembu, } \\
\text { tampune-tampune, } \\
\text { pancung-pancung } \\
\text { cekala. }\end{array}$ & $\begin{array}{l}\text { Motif } \\
\text { anyaman } \\
\text { tepas tetap } \\
\text { dipertahankan. } \\
\text { Sedangkan } \\
\text { ornamen } \\
\text { mengalami } \\
\text { perubahan } \\
\text { minor. }\end{array}$ \\
\hline $\begin{array}{c}\text { Konsep } \\
\text { (Concept) }\end{array}$ & $\begin{array}{l}\text { Produk raga dayang } \\
\text { merupakan salah satu } \\
\text { warisan budaya Karo. }\end{array}$ & $\begin{array}{l}\text { Meningkatkan } \\
\text { nilai produk } \\
\text { (product } \\
\text { value) dan } \\
\text { melestarikan } \\
\text { tacid } \\
\text { knowledge } \\
\text { perajin } \\
\text { sebagai } \\
\text { warisan } \\
\text { budaya di } \\
\text { masa kini. }\end{array}$ \\
\hline $\begin{array}{l}\text { Bentuk } \\
\text { (Shape) }\end{array}$ & $\begin{array}{l}\text { Produk dianyam } \\
\text { dengan mengikuti } \\
\text { bentuk cetakan kayu. } \\
\text { Bentuk yang dihasilkan } \\
\text { pada dasarnya adalah } \\
\text { keranjang persegi, } \\
\text { dengan mulut } \\
\text { keranjang berbentuk } \\
\text { bulat. }\end{array}$ & $\begin{array}{l}\text { Menggunakan } \\
\text { bentuk dasar } \\
\text { simple dan } \\
\text { kubistis. }\end{array}$ \\
\hline
\end{tabular}

\section{2).Tahap Perancangan Produk (Sketsa)}



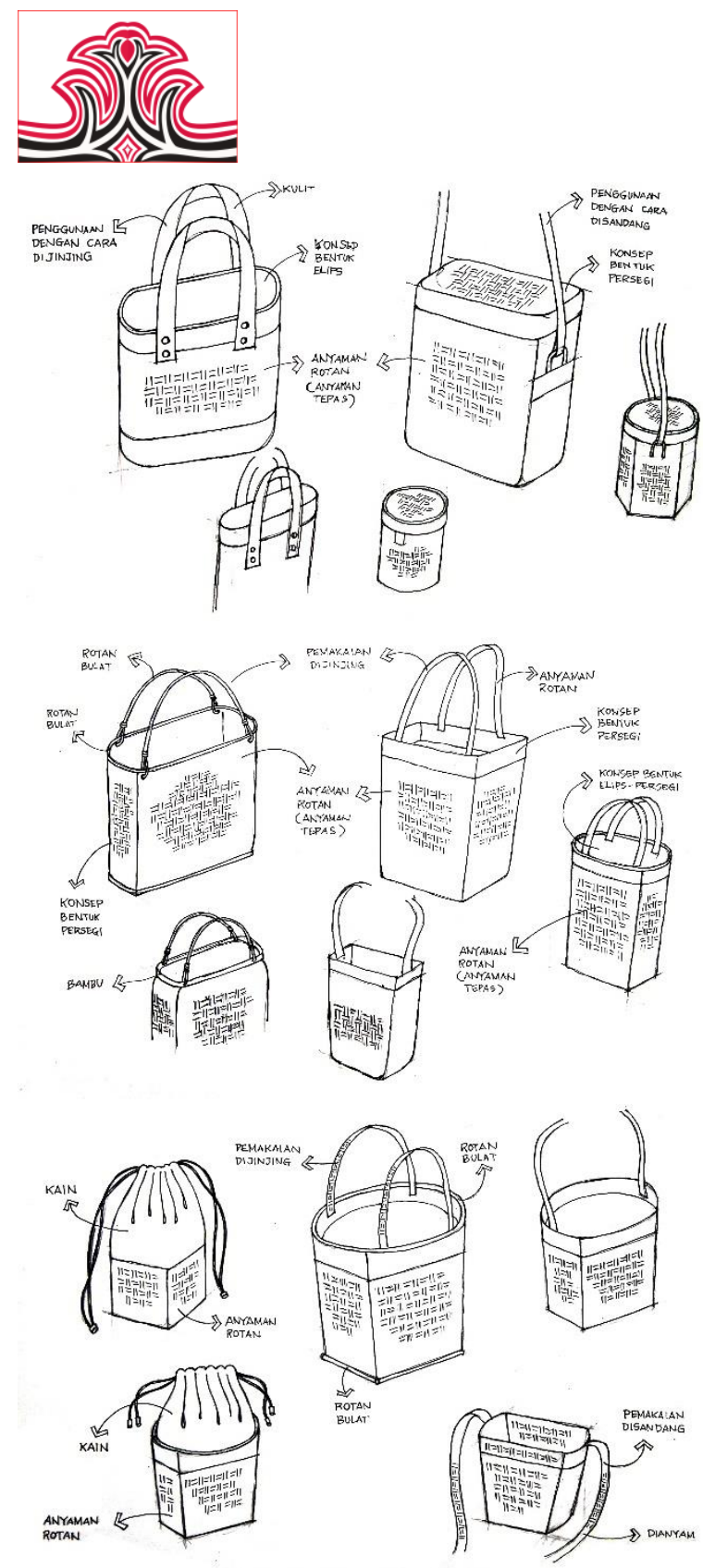

Gambar 6. Alternatif-alternatif Sketsa dengan Bentuk Dasar Kubistis dan Silindris

\section{3).Tahap Pembuatan Purwarupa (Prototype)}

Pembuatan purwarupa produk dilakukan di Desa Kuta Male oleh perajin raga dayang Desa Kuta Male.

\section{KESIMPULAN DAN SARAN}

\section{Kesimpulan}

Ada terdapat beragam kerajinan tradisional Karo, kerajinan tersebut menghasilkan produk-produk tradisional yang memiliki kegunaan dan bentuk yang bermacam-macam. Raga dayang hanyalah salah satunya. Dari beragam produk kerajinan tradisional Karo tersebut mayoritas keberadaannya mulai tergerus oleh zaman dan arus globalisasi. Hanya dalam acara adatlah kerajinan tradisional tersebut masih memiliki tempat dan dipertahankan keasliannya. Raga dayang dan juga produk tradisional lainnya seperti kampil gempang sawa, sumpit, dan amak cur pada dasarnya tidak hanya sebagai benda perlengkapan upacara adat
Gorga : Jurnal Seni Rupa

Volume 09 Nomor 01 Januari-Juni 2020

p-ISSN: 2301-5942 | e-ISSN: 2580-2380

saja, tetapi juga merupakan satu ciri khas budaya yang turun-temurun digunakan. Kebanyakan produk tradisional tersebut sudah tidak dimiliki masyarakat Karo pada umumnya. Akibatnya masyarakat semakin kurang peduli akan bentuk, teknik, dan fungsi produk tersebut karena sifatnya hanya sebagai perlengkapan dalam upacara adat. Dengan kata lain nilai produknya (product value) sudah semakin menurun.

Diversifikasi produk adalah upaya untuk meningkatkan nilai produk (product value). Nilai produk penting agar produk dapat bertahan dan berkembang. Selain meningkatkan nilai produk, diversifikasi produk dilakukan untuk menciptakan desain baru yang mampu menjawab kebutuhan dan selera pasar masa kini. Jika selama ini raga dayang hanya dikenal sebagai produk keranjang tradisional yang digunakan dalam acara adat, dengan diversifikasi produk maka raga dayang dapat dikembangkan menjadi beberapa produk baru yang dapat digunakan oleh masyarakat urban. Diantaranya seperti yang dikembangkan peneliti, sebagai produk tas rotan kontemporer. Selain itu dapat juga dikembangkan sebagai: produk perlengkapan kamar (room accessories), perlengkapan dapur (kitchen accessories), tas keranjang (basket bag), dan keranjang tanaman (planter basket). Raga dayang tetap merupakan produk adat, tetapi produk hasil pengembangan (produk turunannya) akan berkembang menjadi produk kerajinan baru. Pengembangan raga dayang menjadi produk-produk tersebut merupakan salah satu upaya untuk melestarikan raga dayang dan keterampilan perajin yang membuatnya.

Dengan demikian sebagai produk tradisi (produk adati) raga dayang akan tetap lestari, demikian juga tacit knowledge perajinnya juga turut lestari. Tacit knowledge merupakan pengetahuan yang tidak terstruktur, susah untuk didefinisikan dan diberitahukan dengan bahasa formal kepada orang lain dan isinya mencakup pemahaman pribadi. Pengetahuan ini umumnya belum terdokumentasi dan hanya dapat di transfer secara efektif melalui bertatap muka (person to person) (Sis Binus, 2018). Tacit knowledge perajin raga dayang dalam anyaman rotan merupakan modal utama perajin. Kerapihan anyaman rotan yang dihasilkan tidak dimiliki oleh semua perajin rotan. Demikian juga ornamen yang terdapat pada raga dayang merupakan ciri khas tersendiri yang dapat diterapkan pada setiap produk hasil pengembangan. Ini merupakan potensi yang dapat dikembangkan lebih lanjut. 


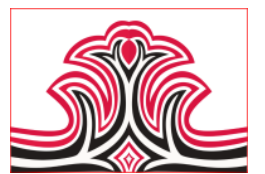

Potensi lainnya adalah kombinasi material. Pada umumnya yang banyak terdapat dan menonjol di tiaptiap daerah adalah perajin bambu, pandan, dan rotan. Ketiganya terdapat di Kabupaten Karo, hanya saja lagi-lagi perajinnya mayoritas mengerjakan produk adat seperti raga dayang dan produk wadah hasil pertanian seperti keranjang sayur dan buah. Padahal ini merupakan potensi daerah, jika perajin mampu melakukan kombinasi material maka dapat dihasilkan produk-produk kerajinan kontemporer (kekinian).

\section{Saran}

Hasil penelitian ini diharapkan menjadi acuan dalam melakukan penelitian lanjutan yang berhubungan dengan kerajinan tradisional Karo pada umumnya dan raga dayang pada khususnya. Beberapa pengembangan yang dapat dilakukan di penelitian selanjutnya, antara lain:

Pengembangan desain melalui eksperimen pengolahan corak (bentuk) dan ukuran anyaman sehingga menghasilkan bentuk anyaman yang berbeda.

Pengembangan desain lewat eksperimen penggunaan pewarna alam pada rotan sehingga menghasilkan berbagai warna yang bersifat sustainable.

Pengembangan desain yang lebih berfokus pada produk fashion seperti tas sandang dan tas jinjing secara berkala, dengan menggunakan teknik anyaman raga dayang atau teknik anyaman tradisional lainnnya.

\section{DAFTAR RUJUKAN}

Martono. (2010). Nilai-Nilai Tradisi Sebagai Inspirasi Pengembangan Desain Kriya Kontemporer. Imaji, Jurnal Seni dan Pendidikan Seni, 08(01), 30-31.

Nugraha, Adhi. (2012): Transforming Tradition: A Method for Maintaining Tradition in a Craft and Design Context. Helsinki: Aalto University.

Sitepu, A.G. (1980). Mengenal Seni Kerajinan Tradisional Karo. Kabupaten Tanah Karo: Departemen P dan K Kabupaten Tanah Karo.

Zulaikha, E., Brereton, M. (2011). Innovation Strategies for Developing the Traditional Souvenir Craft Industry. In The First International Postgraduate Conference on Engineering, Designing and Developing the Built Environment for Sustainable Wellbeing, 27-29 April 2011. Brisbane Qld: Queensland University of Technology.

Sis Binus. (2018). Tacit dan Explicit Knowledge
Gorga : Jurnal Seni Rupa

Volume 09 Nomor 01 Januari-Juni 2020

p-ISSN: 2301-5942 | e-ISSN: 2580-2380

https://sis.binus.ac.id/2018/05/04/15041/. [05 Juni 2019].

[Online]. Tersedia: 